\author{
ОльГА ДоБРЫНИНА
}

\title{
Приобретение права собственности на самовольную постройку
}

В российском праве вопросам самовольной постройки посвящены: статья 222 ГК РФ (Гражданский кодекс Российской Федерации) ${ }^{1}$, Постановление Пленумов ВС РФ (Верховного Суда Российской Федерации) и ВАС РФ (Высшего Арбитражного Суда Российской Федерации) от 29.04.2010 № 10/22 О некоторых вопросах, возникающих в судебной практике при разрешении споров, связанных с защитой права собственности и других вещных прав ${ }^{2}$, Информационное письмо Президиума Высшего Арбитражного Суда от 09.12.2010 № 143 Обзор судебной практики по некоторым вопросам применения арбитражными судами статьи 222 Гражданского кодекса Российской Федерации ${ }^{3}$.

Самовольная постройка - это жилой дом, другое строение, сооружение или иное недвижимое имущество, созданное на земельном участке, не отведенном для этих целей в порядке, установленном законом и иными правовыми актами, либо созданное без получения на это необходимых разрешений или с существенным нарушением градостроительных и строительных норм и правил.

Лицо, которое осуществило самовольную постройку, не приобретает на нее права собственности, и такое строение должно быть снесено. Но существует возможность избежать этого.

Признание права собственности на самовольную постройку осуществляется через суд. При этом должны соблюдаться следующие условия:

- наличие у истца права собственности, пожизненно наследуемого владения, постоянного (бессрочного) пользования на земельный участок, на котором расположен спорный объект;

1 СЗ РФ. 1994 № 32, Ст. 3301.

2 Вестник ВАС РФ. 2010 № 6.

3 Вестник ВАС РФ. 2011 № 2. 
194 | Adam Mickiewicz University Law Review

- соответствие самовольно возведенного объекта требованиям градостроительных, строительных, экологических, противопожарных и иных норм и правил;

- отсутствие нарушений прав и охраняемых законом интересов других лиц;

- отсутствие угрозы жизни и здоровью граждан;

- принятие истцом мер к получению разрешения на строительство и (или) акта ввода объекта в эксплуатацию.

Остановимся на этих условиях более подробно.

Надлежащим истцом по данной категории дел может быть только лицо, имеющее в собственности, пожизненном наследуемом владении, постоянном (бессрочном) пользовании земельный участок, на котором осуществлена постройка. Лицо должно иметь такой статус к моменту рассмотрения дела в суде. Отсутствие этого статуса дает основание для отказа в удовлетворении иска. Если лицо, осуществившее самовольную постройку, не является субъектом одного из перечисленных прав на земельный участок, то оно может рассчитывать только на возмещение затрат на постройку в размере, определенном судом, но не на признание права собственности на самовольную постройку.

Соблюдение данного условия имеет огромную важность т.к. человек, осуществивший для себя самовольную постройку на чужом земельном участке, не только не приобретает права собственности на нее и не вправе ею распоряжаться, но и лишен возможности легализации этой постройки, в то время как владелец земельного участка, даже если он в строительстве не участвовал, этой возможностью обладает. Такое условие обеспечивает защиту владельцев земельных участков от самовольного захвата земли.

Следует отметить, что до 01.09.2006 статья 222 ГК РФ предусматривала возможность признания права собственности на самовольную постройку за лицом, осуществившим строительство на не принадлежащем ему земельном участке, при условии, что данный участок будет в установленном порядке предоставлен этому лицу под возведенную постройку.

Повторное же обращение в суд допустимо, если истец приобретает необходимое право на земельный участок. Обусловлено это тем, что имеет место новое основание иска - наличие у истца права на земельный участок. Причем требование о признании права собственности на самовольную постройку может выступать как в качестве самостоятельного иска, так и в качестве встречного иска (когда к владельцу самовольной постройки предъявляется иск о ее сносе).

Кроме того, в исковом заявлении необходимо указать на отсутствие опасности для жизни и здоровья граждан и на то, что постройка не нарушает их прав. Это подтверждается отсутствием нарушений или наличием таких нарушений, которые будут признаны незначительными. Бремя доказывания указанных фактов несет истец. Он собирает и представляет доказательства, ходатайствует о проведении экспертиз. Рас- 
ходы на это также возмещает истец. В качестве доказательств того, что постройка не представляет угрозы жизни и здоровью граждан, а также соответствует специальным нормам и правилам, истцу необходимо представить положительные заключения уполномоченных органов государственной власти по архитектурно-строительному, пожарному и санитарному надзору, в которых данные обстоятельства должны быть прямо отражены, а сами заключения подписаны уполномоченными должностными лицами. Если представленные им доказательства с учетом доводов от противной стороны не устранят сомнений суда в существовании нарушений или угроз, исходящих от самовольной постройки, иск должен быть отклонен.

В наше время является особо актуальным вопрос о возможности признания права собственности на самовольную постройку, возведенную застройщиком на своем участке без получения административных разрешений, но с соблюдением строительных и градостроительных норм и правил.

По общему правилу, отсутствие разрешения на строительство само по себе не может служить основанием для отказа в иске о признании права собственности на самовольную постройку. В то же время, суду необходимо установить, предпринимало ли лицо, создавшее самовольную постройку, надлежащие меры к ее легализации, в частности, к получению разрешения на строительство и (или) акта ввода объекта в эксплуатацию, а также правомерно ли отказал уполномоченный орган в выдаче такого разрешения или акта ввода объекта в эксплуатацию. В ситуациях, когда административный порядок оформления права собственности на созданный объект недвижимости просто игнорируется, обращение в суд недопустимо. Для большей ясности в фабуле пункта 9 вышеуказанного Обзора от 09.12.2010 указано, что в случае, если истец не предпринимал мер для получения разрешения на строительство до начала строительства или во время проведения работ, то его иск о признании права собственности на самовольную постройку не может быть удовлетворен.

Частым способом узаконивания самовольной постройки является приобретательная давность владения. Согласно п. 1 ст. 234 ГК РФ, лицо - гражданин или юридическое лицо, не являющееся собственником имущества, но добросовестно, открыто и непрерывно владеющее как своим собственным недвижимым имуществом в течение пятнадцати лет, приобретает право собственности на это имущество. При этом сохранение строения не должно нести угрозу жизни и здоровью граждан.

Обязательным условием, необходимым для приобретения права собственности в силу приобретательной давности, является добросовестность на стороне давностного владельца. Добросовестность является оценочными понятием, позволяющим участникам гражданского оборота регулировать свои взаимоотношения, а суду - решать спор с учетом конкретной ситуации. Давностное владение является добросовестным, если лицо, получая владение, не знало и не должно было знать об отсутствии основания возникновения у него права собственности. Открытость давностного владе- 
ния предполагает неутаивание владеемого имущества от других лиц. Принятие лицом обычных мер по обеспечению сохранности имущества не свидетельствует о сокрытии этого имущества. Непрерывность давностного владения означает физическое (фактическое) обладание вещью с постоянным присутствием у него намерения владеть этой вещью как своей без значительных перерывов владения с учетом свойств вещи.

По смыслу п. 12 Обзора от 09.12.2010 приобретение права собственности на самовольную постройку в силу приобретательной давности возможно при наличии следующих условий: приобретение постройки по сделке, добросовестность, открытость и непрерывность владения постройкой как своим собственным недвижимым имуществом в течение срока приобретательной давности, наличие у застройщика права собственности на земельный участок, отсутствие нарушений градостроительных и строительных норм и правил, отсутствие претензий третьих лиц, истечение срока давности по требованию о сносе, единственным признаком самовольности постройки может быть отсутствие разрешения на строительство. Тем самым для приобретения права собственности на самовольное строение в силу давности владения необходимо наличие большого количества условий, в связи с чем, легализация строения будет весьма сложной.

При всем этом, факт самовольного строительства является нарушением закона. И поэтому снос постройки является его наиболее типичным последствием.

Более жесткий подход к самовольному строительству сложился в практике из-за того, что в определенный промежуток времени самовольное строительство рассматривалось как способ преодоления многочисленных бюрократических препятствий при строительстве недвижимости. Это привело к появлению массива строений, не соответствующих градостроительным нормам или расположенных на незаконно занятых участках.

Нарушение закона ведет к ущемлению прав определенных субъектов, поэтому у них возникает право подачи иска о сносе постройки. К таким субъектам относятся:

- собственник земельного участка (в ситуации, когда самовольный застройщик не является собственником земельного участка, на котором возведена постройка). Данное требование собственника земельного участка следует рассматривать как негаторный иск. Вместе с тем возможны, ситуации, в которых земельный участок был захвачен застройщиком, т.е. собственник был полностью отстранен от обладания участком. В этой ситуации иск собственника о сносе постройки будет, по сути, нацелен на возврат владения земельным участком и потому его следует рассматривать как виндикационный. Тонкость состоит в том, что основное требование в данной ситуации - снос строения, удовлетворение которого, тем не менее, не возвращает автоматически земельный участок истцу. В связи с этим, для того, чтобы можно было бы квалифицировать требование как виндикационное, оно должно также содержать в себе просьбу истца о возврате земельного участка из незаконного владения застройщика; 
- лицо, которому принадлежит ограниченное вещное право на земельный участок, на котором расположена постройка [субъект права постоянного (бессрочного) пользования или пожизненно наследуемого владения земельным участком], потому, что самовольная постройка (даже и возведенная с соблюдением строительных норм и правил) нарушает его права;

- лицо, права и законные интересы которого нарушает сохранение самовольной постройки, т.е. любое лицо при наличии интереса в предъявлении подобного рода исков;

- прокурор и иные уполномоченные федеральным законом органы (в частности, орган строительного надзора) вправе обратиться в суд с иском о сносе самовольной постройки, если они защищают публичные интересы. В качестве иных уполномоченных органов может рассматриваться орган местного самоуправления, на территории которого находится самовольная постройка.

Наихудшее положение занимают лица, купившие квартиры у недобросовестного застройщика. Если ответчик, в отношении которого принято решение о сносе самовольной постройки, не осуществлял ее строительство, он вправе обратиться в суд с иском о возмещении убытков к лицу, осуществившему самовольную постройку. На практике в случае принятия негативного судебного решения о сносе самовольной постройки очень трудно вернуть от застройщика все денежные средства, потраченные на приобретение недвижимости, кроме того, возможны длительные судебные тяжбы. Нередко сами покупатели физические и юридические лица обращаются в суд, желая легализовать строение, однако такое обращение может иметь негативное последствие, поскольку судом постройка может быть признана самовольной и может быть принято решение о сносе.

К сожалению, юридические и физические лица, имеющие право собственности на постройки, не могут иметь 100\% защиты своих прав. Это подтверждается судебной практикой. Так, в Обзоре от 09.12.2010 арбитражный суд в одном из решений закрепил, что наличие свидетельства о собственности на объект недвижимого имущества не исключает возможности признания такого объекта самовольной постройкой. Аналогичная позиция содержится в пункте 23 Постановления Пленумов ВС РФ и ВАС РФ от 29.04.2010.

При рассмотрении вопроса о сносе самовольной постройки могут возникнуть некоторые вопросы. В частности, если самовольная постройка находится на территории муниципального образования, то могут ли органы местного самоуправления снести ее в административном порядке? В комментариях к законодательству нет единого ответа. Есть мнение, в соответствии с которым административные органы вправе принимать решение о сносе самовольно возведенной постройки, так как такое полномочие может быть закреплено в регламенте за соответствующим административным органом. С другой стороны, есть мнение о том, что принятие решения о сносе самовольной по- 
стройки в административном порядке нарушает положения Конституции РФ (ст. 35). Однако практика решает данный вопрос вполне однозначно - действующее законодательство не предоставляет административным органам права принимать решения о сносе самовольных построек, следовательно, такие решения может принимать только суд.

Следующая важная проблема, возникающая при разрешении споров о сносе самовольной постройки, заключается в определении ответчика по делу. Самый очевидный вариант - это лицо, создавшее самовольную постройку. Но не всегда вопрос с ответчиком разрешается так легко. Если самовольная постройка передана во владение другому лицу, ответчиками по иску являются, во-первых, владелец самовольной постройки (так как именно он в случае удовлетворения иска будет выселен из строения) и, вовторых, самовольный застройщик (так как на него суд должен будет возложить расходы по сносу постройки). Если же застройщик не может быть привлечен к участию в деле (например, в связи со смертью, ликвидацией), то единственным ответчиком по иску о сносе постройки будет ее владелец. В ситуациях, когда владение постройкой осуществляется застройщиком, он и является ответчиком по иску о сносе.

Общий вывод, который можно сделать на основе рассмотренных проблем: право собственности, в частности, на строение, действительно является священным и нерушимым, но лишь в том случае, если оно было получено на законных основаниях, с соблюдением требований, установленных законом.

\section{Биографическая аннотация:}

Ольга Добрынина - Иркутский государственный университет, Юридический институт. Научные интересы: вопросы права собственности на недвижимость, уголовное право, уголовный процесс.

SUMMARY

\section{The acquisition of the ownership of the unauthorised construction}

The study aims at an evaluation of the acquisition of the ownership of the unauthorised construction. The author present this form of the acquisition of the right to property in the civil code of the Russian Federation emphasising the necessity of fulfilling law norms. KEYWORDS: unauthorised construction, acquisition of the ownership, civil law 